\title{
Major complications of post-chemotherapy retroperitoneal lymph node dissection in a contemporary cohort of patients with testicular cancer and a review of the literature
}

Christian Guido Ruf ${ }^{1,2+}$, Simon Krampe ${ }^{1 \dagger}$, Cord Matthies ${ }^{1}$, Petra Anheuser ${ }^{3}$, Tim Nestler ${ }^{4}$, Jörg Simon ${ }^{5}$, Hendrik Isbarn ${ }^{6}$ and Klaus Peter Dieckmann ${ }^{3,7^{*}}$ (D)

\begin{abstract}
Background: Post-chemotherapy retroperitoneal lymph node dissection (pc-RPLND) is one cornerstone in the clinical management of patients with nonseminomatous testicular germ cell tumours (GCT). A wide range of complication rates in this type of surgery is reported so far. We retrospectively evaluated the frequency of major complications by using the Clavien-Dindo classification and analysed the influence of various clinical factors on complication rates in Pc-RPLND.

Methods: We retrospectively analysed $146 \mathrm{GCT}$ patients undergoing pc-RPLND. Complications of grade III-V according to the Clavien-Dindo classification occurring within 30 days after surgery were registered along with the following clinical factors: age, body mass index (BMI), duration of surgery, number of anatomic fields resected, side of primary tumour, histology of surgical specimen, histology of primary tumour, and total dose of cisplatin applied prior to surgery. For comparison, we also evaluated 35 chemotherapy-naive patients with primary RPLND and 19 with laparoscopic RPLND. We analysed types and frequencies of the various complications as well as associations with clinical factors using descriptive statistical methods.

Results: A total of $14.4 \%$ grade III-IV complications were observed in PC-RPLND, and $8.6 \%$ and $5.3 \%$ in primary and in laparoscopic RPLND, respectively. There was no perioperative mortality. Lymphocele was the most frequent adverse event (16\% of grade III-IV complications). Operation time $>270 \mathrm{~min}(p=0.001)$ and vital cancer in the resected specimen $(p=$ 0.02 ) were significantly associated with higher complication rates. Left-sided resection fields involved two-fold higher complication rates, barely missing statistical significance $(p=0.06)$.

(Continued on next page)
\end{abstract}

\footnotetext{
* Correspondence: Dieckmannkp@t-online.de

${ }^{\dagger}$ Christian Guido Ruf and Simon Krampe contributed equally to this work.

${ }^{3}$ Department of Urology, Albertinen Krankenhaus Hamburg, Suentelstrasse 11a, 22457 Hamburg, Germany

${ }^{7}$ Department of Urology, Asklepios Klinik Altona, Paul Ehrlich Strasse 1, 22763 Hamburg, Germany

Full list of author information is available at the end of the article
}

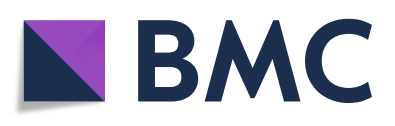

(- The Author(s). 2020 Open Access This article is licensed under a Creative Commons Attribution 4.0 International License, which permits use, sharing, adaptation, distribution and reproduction in any medium or format, as long as you give appropriate credit to the original author(s) and the source, provide a link to the Creative Commons licence, and indicate if changes were made. The images or other third party material in this article are included in the article's Creative Commons licence, unless indicated otherwise in a credit line to the material. If material is not included in the article's Creative Commons licence and your intended use is not permitted by statutory regulation or exceeds the permitted use, you will need to obtain permission directly from the copyright holder. To view a copy of this licence, visit http://creativecommons.org/licenses/by/4.0/. The Creative Commons Public Domain Dedication waiver (http://creativecommons.org/publicdomain/zero/1.0/) applies to the data made available in this article, unless otherwise stated in a credit line to the data. 


\begin{abstract}
(Continued from previous page)
Conclusions: PC-RPLND involves a grade III-V complication rate of $14.4 \%$. Prolonged operation time and vital cancer in the residual mass are significantly associated with higher complication rates. The Clavien-Dindo classification system may allow inter-observer variation in rating complication grades, which may represent one reason for the wide range of reported RPLND complication rates. RPLND represents major surgery and surgeons active in this field must be competent to manage adverse events.
\end{abstract}

Keywords: Testicular germ cell tumour, Retroperitoneal lymph node dissection, Lymphocele, Nonseminoma, Surgical complication

\section{Introduction}

Testicular germ cell tumours (GCT) represent the prototype of curable malignancies $[1,2]$. The mainstays of therapy are cisplatin-based chemotherapy and retroperitoneal lymph node dissection (RPLND). The first ever reported RPLND was performed by the Swiss surgeon Theodor Kocher in 1883 [3]. Since this pioneering work, the procedure has received an ongoing number of surgical and perioperative refinements [4]. Today, RPLND is considered a safe surgical procedure in experienced hands [5].

There are several types of RPLND, the most frequent being post-chemotherapy RPLND (pc-RPLND) which is used for surgical resection of residual retroperitoneal masses after chemotherapy of nonseminomatous GCT [6, 7]. Primary RPLND (p-RPLND) is used less frequently in select cases with clinical stage (CS) 1 and with marker-negative CS 2, in which the operation is performed for diagnostic and therapeutic purposes [8-10]. In recent years, another type of RPLND has come into use, the laparoscopic RPLND (lRPLND) [11].

Surgical complications are an ongoing issue in RPLN D. With improvements of surgical and anaesthesiologic techniques the frequencies of complications have significantly decreased over the last decades. The reported rates of surgical complications of RPLND vary widely between $1 \%$ and almost $50 \%[12,13]$.

The wide range of reported complication rates can be attributed to two aspects. First, although all types of RPLND are considered major abdominal surgery, pc-RPLND is technically much more challenging than primary resections due to desmoplastic reactions around the great abdominal vessels as an effect of chemotherapy [14, 15]. Sometimes these changes may hinder the access to the natural layers for dissection in the retroperitoneum, thus triggering the need for adjunctive surgical measures [16]. Therefore, pc-RPLND usually involves higher rates of complications than p-RPLN $D$ [17]. The second reason for the documented range of complications is methodological. Adverse events occurring during surgery or postoperatively may be rated quite differently by various surgeons. To objectify the appraisal of adverse events occurring postoperatively, the international Clavien-Dindo (CD) classification system of for assessing surgical complications was introduced in 2004 [18]. However, even when this gold standard is applied, interobserver variability still occurs [19], particularly with respect to minor complications [20, 21]. Furthermore, minor complications not affecting the over-all success of surgery may be illdocumented in archival patient files. Thus, retrospective evaluations of complication rates may overlook or misclassify these minor events and thus result in under-reporting of such complications.

The aim of the present study is to retrospectively analyse the surgical complication rates observed in a contemporary cohort of patients undergoing RPLND in two testicular cancer centres in Germany. To obtain meaningful data comparable to other series, we focused on the most frequent type of this surgery (pc-RPLND), and we rated the complications according to the $\mathrm{CD}$ classification system [18]. Furthermore, to avoid misclassifying minor complications in a retrospective chart review, we restricted our analysis to complications grade III to $\mathrm{V}$ of the CD system, which represent major complications requiring invasive or otherwise extended therapeutic measures. We also analysed whether particular clinical features are associated with certain complications.

\section{Methods}

The electronic patient archives of Bundeswehrkrankenhaus Hamburg, Germany and Albertinen-Krankenhaus Hamburg, Germany, were retrospectively searched for cases with testicular cancer undergoing RPLND from 2000 to 2017. Three types of surgery were originally included in this study: post-chemotherapy RPLND (pc-RPLND) in cases with residual retroperitoneal masses after chemotherapy, open primary RPLND in CS 1 and CS2 cases (p-RPLND), and laparoscopic primary RPLND (l-RPLND). Four experienced surgeons performed these operations. Post-chemotherapy resections were performed as unilateral template resections in the presence of small residual masses. Larger residual masses usually required bilateral resections. p-RPLND was performed using the Indiana nerve-sparing technique in modified templates [22, 23]. In CS2 patients, bilateral dissections were performed with nerve sparing whenever possible. Laparoscopic resections were confined to unilateral templates. All patients were managed according to contemporary guidelines [24, 25]. 
Complications were defined as any adverse event occurring intraoperatively or within 30 days after surgery according to the CD system [18]. Adjunctive procedures during surgery such as nephrectomy, bowel resection or vascular repairs were not considered as complications when they were required for completeness of excision. The following data were abstracted from the files: type of RPLND (p-RPLND, l-RPLND, pcRPLND), histology of the primary testicular tumour (nonseminoma/seminoma/teratoma as component of nonseminomatous tumour), histology of resected specimen (vital GCT, teratoma, necrosis), patient's age, body mass index (BMI), duration of the surgical procedure, number of topographic fields resected according to the Weissbach field classification [26], laterality (left/right side), and in pc-RPLND also cumulative dosage of cisplatin applied prior to surgery $(<500 \mathrm{mg} / 500$ $700 \mathrm{mg} />700 \mathrm{mg}$ ); complications (yes/no), grade of complication according to the $\mathrm{CD}$ classification [18].

For final analysis, only major complications were included (grade III-V CD system [18]). In patients developing more than one complication, only the most severe event was included into the analysis. Our analysis involved four steps: (1) we listed the types of adverse events observed. (2) The frequency of grade III-V complications was assessed according to the three types of surgery. (3) In pc-RPLND, correlations between complications and clinical factors were analysed. Due to the retrospective evaluation, information regarding the various clinical factors was not available in all patients and thus, sample sizes of subgroups vary in this analysis due to missing data. (4) We compared our findings with complication rates of RPLND documented in the literature from 2000 to 2020.

The statistical analysis was computed with SPSS software (Version 20, IBM, USA), mainly employing descriptive statistical methods. The chi-squared test was used for statistical comparisons of proportions. A $p$ value $<$ 0.05 was considered significant.
Ethical consent was obtained from the institutional ethical committee (AEK, U03, Hamburg 12 June 2016). All study activities conformed to the Helsinki Declaration of the World Medical Association (as amended by the $64^{\text {th }}$ General Assembly, 2013).

\section{Results}

A total of 201 patients were identified, thereof 147 with pcRPLND, 35 with p-RPLND and 19 with l-RPLND. Clinical details of these patients are listed in Table 1. One patient with pc-RPLND was excluded from further analysis due to missing data on complications. A total of 200 patients were eligible for further analysis. About one quarter of the patients had been included in previous reports $[9,27]$. Histologic examination of surgical specimens of pc-RPLND yielded necrosis/fibrosis, teratoma, and vital cancer in $44.1 \%, 44.8 \%$, and $11.1 \%$, respectively. Among the entire cohort of 200 patients, we identified a total of 98 patients (49\%) where any type of complication was documented, thereof 25 patients (12.5\%) with grade III-IV complications (complications requiring surgical or interventional measures) according to the $\mathrm{CD}$ classification. There was no grade $\mathrm{V}$ complication (perioperative death). Symptomatic lymphocele (Fig. 1) was the most frequent grade III-IV adverse event observed in 4 patients (16\% of all grade III-IV complications, $2 \%$ of all patients included in the cohort). A detailed synopsis of the clinical features of major complications is presented in Table 2.

A comparison of the complication rates between the three types of RPLND revealed a higher rate of grade III$\mathrm{V}$ complications in pc-RPLND (14.4\%), compared to primary $(8.6 \%)$ and laparoscopic resections (5.3\%). However, this difference is not statistically significant (Table 3).

There was no significant change of grade III-IV complication rates over time. During the first and the second half of the time span of our survey (2000-2017), the complication rates were $13.2 \%$ and $15.1 \%$, respectively.

Table 1 Clinical details of patients included in the study

\begin{tabular}{|c|c|c|c|}
\hline & $\begin{array}{l}\text { Post-chemotherapy RPLND } \\
(n=147)\end{array}$ & $\begin{array}{l}\text { Primary RPLND } \\
(n=35)\end{array}$ & $\begin{array}{l}\text { Laparoscopic RPLND } \\
(n=19)\end{array}$ \\
\hline $\begin{array}{l}\text { Age (years) } \\
\text { median (IQR) } \\
\text { range }\end{array}$ & $\begin{array}{l}30(23-37) \\
14-82\end{array}$ & $\begin{array}{l}29(24-37) \\
16-57\end{array}$ & $\begin{array}{l}31(25-35) \\
17-55\end{array}$ \\
\hline $\begin{array}{l}\mathrm{BMI}\left(\mathrm{kg} / \mathrm{m}^{2}\right) \\
\text { median }(\mathrm{IQR}) \\
\text { range }\end{array}$ & $\begin{array}{l}25.2(22.6-28.4) \\
17-37\end{array}$ & $\begin{array}{l}25.8(21.7-27.7) \\
17-46\end{array}$ & $\begin{array}{l}26.0(23.1-28.7) \\
20-38\end{array}$ \\
\hline Seminoma as primary tumour & $17 / 147(11.6 \%)$ & $1 / 35(2.9 \%)$ & $0 / 19(0 \%)$ \\
\hline Teratoma predominant in primary tumour & 18/147 (12.2\%) & $5 / 35(14.3 \%)$ & $4 / 19(21.1 \%)$ \\
\hline $\begin{array}{l}\text { Operation time (min) } \\
\text { median (IQR) } \\
\text { range }\end{array}$ & $\begin{array}{l}269(215-378) \\
66-735\end{array}$ & $\begin{array}{l}246(201-329) \\
50-440\end{array}$ & $\begin{array}{l}165(106-207) \\
57-234\end{array}$ \\
\hline Median number of fields resected ${ }^{a}$ & 5 & 4 & 4 \\
\hline Primary tumour right-sided & $68 / 147(46.3 \%)$ & $14 / 35(40 \%)$ & $7 / 19(36.8 \%)$ \\
\hline
\end{tabular}

${ }^{\mathrm{a}}$ According to Weissbach Field Classification [26] 


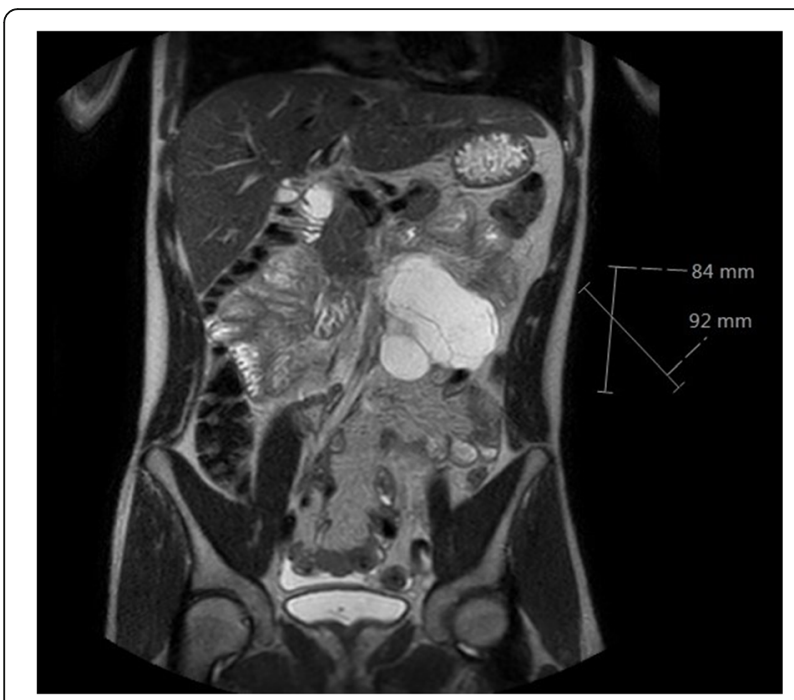

Fig. 1 Left-sided multi-chambered intraabdominal lymphocele arising after post-chemotherapy RPLND. Magnetic resonance imaging, T2-weighted imaging, coronal sectioning. This lymphocele resolved spontaneously within 3 months

The correlations of complications in pc-RPLND and various clinical factors are listed in Table 4. Significantly higher complication rates were observed in patients with duration of surgery exceeding $4 \frac{1}{1 / 2} \mathrm{~h}$ and in those with viable cancer in the resected specimen. A strong trend was found for a higher complication rate in left-sided compared to right- sided resections $(p=0.06)$. A slightly weaker trend towards increased complication rates was observed in obese patients with $\mathrm{BMI} \geq 30 \mathrm{~kg} / \mathrm{m}^{2}(p=0.18)$. None of the other clinical factors evaluated were associated with complication rates.

\section{Discussion}

This study confirms that pc-RPLND with a rate of $14.4 \%$ of grade III-V complications according to the CD classification [18] is justifiably considered major surgery. Factors influencing the complication rates are duration of surgery $\geq 41 / 2 h$, vital cancer in the resected specimen and, surprisingly, left-sided post-chemotherapy resections. The most frequent type of complication is the occurrence of lymphoceles.

A vast number of studies on various aspects of RPLND have been published since the beginning of this century. However, only few provided specific details on complication rates. An overview of contemporary studies providing data on grade III-V complications utilizable for comparison is given in Table 5. Five studies reported higher rates than the present series [27-31], 10 lower [8, 12, 15, 32-39].

No perioperative mortality was observed in our series, which is consistent with other recent reports $[8,13,27$, $30,31,33,34,36$ ]. Low mortality rates of 0.20 to $1.6 \%$ $[12,29,32,35,38,39]$ were reported in some other studies (Table 5). In a Dutch series, one death due to anaesthesiological problems was reported [40]. Based on these

Table 2 Synopsis of types of grade III-IV complications according to Clavien-Dindo classification [18] observed in all RPLNDs ( $n=$ 200) ranked by over-all frequency

\begin{tabular}{|c|c|c|c|c|c|}
\hline Type of complication & $\begin{array}{l}(n) \\
\text { total number } \\
\text { of events }\end{array}$ & $\begin{array}{l}(\%) \\
\text { of all RPLNDs } \\
(n=200)\end{array}$ & $\begin{array}{l}(n) \\
\text { in pc-RPLND } \\
\text { patients }\end{array}$ & $\begin{array}{l}(\%) \\
\text { in pc-RPLND } \\
\text { patients } \\
(n=146)\end{array}$ & $\begin{array}{l}\text { (\%) } \\
\text { of all grade III-IV } \\
\text { complications }\end{array}$ \\
\hline Lymphocele & 4 & $2 \%$ & 3 & $2.1 \%$ & $16 \%$ \\
\hline lleus & 3 & $1.5 \%$ & 3 & $2.1 \%$ & $12 \%$ \\
\hline Intraoperative trauma to ureter & 3 & $1.5 \%$ & 3 & $2.1 \%$ & $12 \%$ \\
\hline Wound healing problems & 3 & $1.5 \%$ & 2 & $1.4 \%$ & $12 \%$ \\
\hline Postoperative haemorrhage & 2 & $1 \%$ & 0 & $0 \%$ & $8 \%$ \\
\hline Pneumonia & 1 & $0.5 \%$ & 1 & $0.7 \%$ & $4 \%$ \\
\hline Gastroparesis & 1 & $0,5 \%$ & 1 & $0.7 \%$ & $4 \%$ \\
\hline Ectasia of renal pelvis & 1 & $0.5 \%$ & 1 & $0.7 \%$ & $4 \%$ \\
\hline Pancreatitis & 1 & $0.5 \%$ & 1 & $0.7 \%$ & $4 \%$ \\
\hline Wound opening with bowel protrusion & 1 & $0.5 \%$ & 1 & $0.7 \%$ & $4 \%$ \\
\hline Retroperitoneal haematoma & 1 & $0.5 \%$ & 1 & $0.7 \%$ & $4 \%$ \\
\hline Pneumothorax & 1 & $0.5 \%$ & 1 & $0.7 \%$ & $4 \%$ \\
\hline Cardiac arrhythmia & 1 & $0.5 \%$ & 1 & $0.7 \%$ & $4 \%$ \\
\hline Atelectasis of lower lung lobe & 1 & $0.5 \%$ & 1 & $0.7 \%$ & $4 \%$ \\
\hline $\begin{array}{l}\text { Systemic inflammatory response syndrome (SIRS) with } \\
\text { disseminated intravascular coagulation (DIC) }\end{array}$ & 1 & $0.5 \%$ & 1 & $0.7 \%$ & $4 \%$ \\
\hline
\end{tabular}


Table 3 Major complication rates (grade III-V, Clavien-Dindo classification) in relation to type of RPLND

\begin{tabular}{llll}
\hline & $\boldsymbol{n}$ & $\begin{array}{l}\text { Complication grade III-IV } \\
\boldsymbol{n}(\%)\end{array}$ & $\boldsymbol{p}$ value * \\
\hline Post-chemotherapy RPLND & 146 & $21(14.4 \%)$ & $3(8.6 \%)$ \\
Primary RPLND & 35 & $1(5.3 \%)$ & 0.39 \\
Laparoscopic RPLND & 19 & \\
\hline
\end{tabular}

* chi squared test

data, it may be concluded that perioperative death is exceptionally rare in pc-RPLND.

The reported range of major complications is amazingly wide, from as low as $1.2 \%$ to up to $23.3 \%$ (Table 5). There are at least three factors that may explain these widely divergent rates: (1) surgical experience, (2) patient-related factors and extent of the surgical procedure, (3) methodological discrepancies with regard to adherence to the CD classification system.

(1) The data compiled in Table 5 indicate that surgical experience might be an important factor influencing the incidence of adverse events. In our opinion, the average number of cases operated per year (caseload) should be considered an indicator for experience, rather than the total number of patients involved in a report. Accordingly, the two studies with the highest caseloads (84/year and 19.2/year) reported the lowest incidences of complications [12, 32]. Conversely, the two studies reporting the highest complication rates had much lower caseloads of 4.9/year and 10.3/year [28, 30]. The significance of individual surgical experience is certainly paramount [41], and therefore, it has repeatedly been advocated that major surgery such as RPLND should be performed only in dedicated centres of excellence [5, 42-45]. In conclusion, one reason for the great variance among reported complication rates may be surgical experience.

(2) One patient-related factor that was shown to be associated with higher complication rates is the presence of vital cancer in the resected specimen. This association might be attributed to the size of resected tumours, because larger residual masses contain vital cancer more frequently than small masses [46]. As size of the residual mass is significantly associated with adjunctive surgical measures [47], tumour size could be the underlying reason for the association of vital cancer in the specimen with complication rates.

Operation time over $4 \frac{1 / 2}{2}$ hours was also shown to be associated with higher complication rates (Table 4).

Table 4 Grade III-IV complications of pc-RPLND according to Clavien-Dindo classification in relation to clinical factors

\begin{tabular}{|c|c|c|c|c|}
\hline Clinical factor evaluated & Eligible total $(n)$ & $\begin{array}{l}\text { Categories } \\
\text { (eligible in category, } n \text { ) }\end{array}$ & Patients with complications $(n),(\%)$ & $p$ value $^{\mathrm{b}}$ \\
\hline \multirow[t]{2}{*}{ Age } & 143 & $\leq 30$ years $(n=76)$ & $10(13.2 \%)$ & 0.59 \\
\hline & & $>30$ years $(n=67)$ & $11(16.4 \%$ & \\
\hline \multirow[t]{2}{*}{ BMI } & 131 & $\leq 29 \mathrm{~kg} / \mathrm{m}^{2}(n=103)$ & $12(11.7 \%)$ & 0.18 \\
\hline & & $\geq 30 \mathrm{~kg} / \mathrm{m}^{2}(n=28)$ & $6(21.4 \%)$ & \\
\hline \multirow[t]{2}{*}{ Laterality of primary } & 137 & Right-sided ( $n=68)$ & $6(8.8 \%)$ & 0.06 \\
\hline & & Left-sided $(n=69)$ & $14(20.3 \%)$ & \\
\hline \multirow[t]{2}{*}{ Duration of surgery } & 67 & $\leq 269 \min (n=34)$ & $(0 \%)$ & 0.001 \\
\hline & & $\geq 270 \min (n=33)$ & $9(27.3 \%)$ & \\
\hline \multirow[t]{3}{*}{ Cisplatin dosage } & 93 & $<500 \mathrm{mg}(n=18)$ & $2(11.1 \%)$ & 0.83 \\
\hline & & $500-700 \mathrm{mg}(n=45)$ & $4(8.9 \%)$ & \\
\hline & & $>700 \mathrm{mg}(n=30)$ & $4(13.3 \%)$ & \\
\hline \multirow[t]{2}{*}{ Number of resection fields ${ }^{a}$} & 139 & $\leq 5(n=82)$ & $10(12.2 \%)$ & 0.54 \\
\hline & & $>5(n=57)$ & $9(15.8 \%)$ & \\
\hline \multirow[t]{2}{*}{ Teratoma in primary } & 92 & Yes $(n=18)$ & $2(11.1 \%)$ & 0.83 \\
\hline & & No $(n=74)$ & $7(9.5 \%)$ & \\
\hline \multirow[t]{3}{*}{ Histology of resected specimen } & 145 & Necrosis/fibrosis $(n=64)$ & $7(10.9 \%$ & 0.02 \\
\hline & & Teratoma $(n=65)$ & $8(12.3 \%)$ & \\
\hline & & Viable cancer $(n=16)$ & $6(37.5 \%)$ & \\
\hline
\end{tabular}

${ }^{a}$ Resection fields according to Weissbach field classification [26]

${ }^{\mathrm{b}}$ Chi-squared test 
Table 5 Complication rates of pc-RPLND according to grade III-V of the Clavien-Dindo classification-survey of the literature

\begin{tabular}{|c|c|c|c|c|c|c|c|}
\hline \multirow[b]{3}{*}{ First author } & \multirow[b]{3}{*}{ Ref \# } & \multirow[b]{3}{*}{ Year } & \multirow[b]{3}{*}{ Institution/country } & \multirow[b]{3}{*}{$\mathbf{n}$} & \multirow{3}{*}{$\begin{array}{l}\text { Caseload } \\
\text { pts/year }\end{array}$} & \multicolumn{2}{|c|}{ Complications } \\
\hline & & & & & & Grade III-IV & Grade V \\
\hline & & & & & & $\%$ & $\%$ \\
\hline Hendry $^{a}$ & 32 & 2002 & London /UK & 442 & 19.2 & 5.6 & 1.1 \\
\hline Pottek $^{\mathrm{a}}$ & 27 & 2004 & Hamburg/Ger & 207 & 10.4 & 15.9 & 0 \\
\hline Spiess $^{\mathrm{a}}$ & 28 & 2006 & Houston/USA & 236 & 10.3 & 23.3 & 1.3 \\
\hline Williams ${ }^{a}$ & 8 & 2009 & Boston/USA & 92 & 11.5 & 9.8 & 0 \\
\hline Flechon $^{a}$ & 29 & 2010 & Lyon/France & 151 & 13.0 & 14.6 & 0.7 \\
\hline Subramanian & 15 & 2010 & Cleveland/USA & 96 & 13.0 & 7 & 1 \\
\hline Luz & 30 & 2010 & Montreal/Can & 73 & 4.9 & 19.2 & 0 \\
\hline Djaladat & 33 & 2012 & Los Angeles/USA & 85 & 12.1 & 1.2 & 0 \\
\hline Cary & 12 & 2015 & Indiana/USA & 755 & 83.9 & 1.3 & 0.3 \\
\hline Considine & 34 & 2016 & Dublin/Ireland & 78 & n.a. & 9.0 & 0 \\
\hline Dusaud & 35 & 2016 & Multicenter/France & 469 & n.a. & 2.0 & 0.2 \\
\hline Wells & 31 & 2016 & Multicenter/UK & 162 & n.a. & 17.2 & 0 \\
\hline Paffenholz & 36 & 2018 & Cologne/Ger & 162 & 10.8 & 7.4 & 0 \\
\hline Hiester & 37 & 2019 & Düsseldorf/Ger & 171 & 10.7 & 5 & 1 \\
\hline Gerdtsson & 38 & 2020 & Multicenter Sweden/Norway & 97 & 5.0 & 12.3 & 0.3 \\
\hline Blok & 39 & 2020 & Utrecht/NL/2 ctrs & 124 & n.a. & 9.7 & 1.6 \\
\hline Present series & & 2020 & Hamburg/Ger/2 ctrs & 146 & 11.1 & 14.4 & 0 \\
\hline
\end{tabular}

n.a not available, ctrs centers, pts patients, Can Canada, Ger Germany, NL Netherlands, UK United Kingdom

${ }^{a}$ These studies did not report according to the Clavien-Dindo system. In these series, data were rated in analogy to the system, and deaths were considered grade $\mathrm{V}$

Caseloads were calculated from published reports according to numbers of patients and time span of patient accrual

However, it is rational to assume that operation time itself is not the cause of complications; rather, prolonged operation time is caused by complex intraoperative situations that may trigger complications.

Generally, there is strong evidence for a significant association between age and comorbidity with the frequencies of surgical complications in major urological procedures [48]. However, testicular cancer is a malignancy typically afflicting young men with no or little comorbidity. Accordingly, in patients aged $\geq 31$ years, we did not observe higher rates of grade III-IV complications. In contrast, other reports considered age as a risk factor for intraoperative complications. In a national cohort in the USA, a higher number of adjunctive surgical measures had been employed in patients 35 years or older undergoing RPLN D [16]. However, intraoperative adjunctive measures do not directly translate into higher rates of postoperative complications as shown in the current study.

Obesity is another well-known factor impacting the incidence of adverse events upon surgery, mainly wound healing issues, thromboembolic events and respiratory postoperative problems $[49,50]$. Accordingly, we found a two-fold higher rate of grade III-IV complications in patients with BMI $\geq 30 \mathrm{~kg} / \mathrm{m}^{2}$, but the difference was not statistically significant, probably due to small sample size.
Curiously, in the present series, left-sided procedures involved a two-fold higher complication rate than rightsided RPLND, and to our knowledge, this observation has not been reported previously. The result closely misses statistical significance $(p=0.06)$. Yet, the association seems reasonable because left-sided template resections sometimes require extended mobilisation of small bowels and colon, and this surgical manoeuvre may precipitate complications, e.g. small bowel obstruction and postoperative ileus. In accordance with our finding, a Scandinavian study reported a higher rate of adjunctive measures in left-sided resections [38].

In summary, patient-related factors such as comorbidities, duration of surgery, laterality of procedure, and histology of resected specimen may affect complication rates. Varying incidences of patient-related factors in studies reported in the literature may therefore partly explain the wide range of complications in pc-RPLND.

(3) The third factor affecting the reported complication rates of RPLND is the methodology for the assessment of complications. For comparing surgical complication rates among institutions or studies it is paramount to define and classify adverse events in a uniform and objective manner [51]. Although strong efforts have been made to classify complications in an unambiguous manner by introducing the CD classification [18], there is still evidence for 
interobserver discrepancies regarding the assessment of adverse perioperative events $[19,20]$ particularly concerning surgical site infections [52]. This was demonstrated in a Canadian survey among urologic surgeons which found an interrater agreement rate of $75 \%$ [53].

The CD system is largely based on the extent of measures to manage complications [54]. Major complications necessitating clearly defined interventions usually involve high interobserver agreement rates. Conversely, minor complications of grade I-II requiring only conservative measures or just observation involve much more interobserver variation. This was demonstrated in an international survey of 98 urologists, who rated 70 different complications of nephrolithotomy [21]. In view of several weaknesses of the CD system, modifications have been suggested [55], but currently it is still considered the gold standard [54].

In our evaluation of complications of RPLND, we rated a high number of grade I-II complications. In final analysis, we realized that most of these events originally considered as complications were indeed asymptomatic lymphoceles that had been detected incidentally on routine postoperative ultrasound examinations. Other findings such as redness and anejaculation also did not alter the postoperative course. Clearly, these findings are prone to interobserver variation. Therefore, we elected to focus on clearly defined major complications (grade III-V of the CD classification). This is based on empirical evidence that interobserver agreement rates are highest regarding grade $\mathrm{V}$ complications (death) and decrease in lower complication grades [21].

With respect to the widely divergent complication rates of pc-RPLND (1.2-23.3\%) summarized in Table 5, we must certainly acknowledge that apart from surgical expertise and patient-related factors, methodological problems of rating the various types of complications may also contribute to the large variance of reported results. Accordingly, it is not yet empirically possible to clearly define a benchmark or an acceptable upper limit of complication rates.

The most frequent complication in our series was lymphocele formation (16\% of all grade III-IV complications in all types of RPLND). Accumulation of lymphatic fluid in the abdomen is thought to derive from dissecting and opening of lymphatic vessels without proper ligation during resection of retroperitoneal masses. Whether perioperative low-dose heparin administration for prophylaxis of thromboembolic events may contribute to the development of lymphoceles remains unclear. Vahlensieck was the first to document postoperative retroperitoneal lymphoceles following p-RPLND in 1973 [56]. Low-dose radiotherapy was used to manage the complication in those cases. In contemporary series of $\mathrm{p}$ RPLND and pc-RPLND, reported rates of lymphocele formation range from 0 to $14.6 \%$, with the majority of studies reporting low rates of 1.5 to $5 \%$ [15, 27, 40, 47, 57], but some also report higher rates of $10.9 \%$ [30], 11\% [38], and 14.6\% [29]. Probably, the wide range of lymphocele occurrences reported can be attributed to differences in coding systematics. One may assume that lymphoceles were not accounted for at all in many of the previous reports, unless invasive interventions such as insertion of drainage tubes were required. Accordingly, the case shown in Fig. 1 had only very mild abdominal discomfort according to grade I or II of the CD system despite the rather high volume of lymphatic fluid accumulating in the abdominal cavity. This lymphocele resolved completely within 3 months without specific measures.

The main limitation of our study is the retrospective mode of data acquisition. As not all of the adverse events were unequivocally documented in the patient files, some events might have been missed or graded inappropriately. Due to small numbers of events, statistical analysis did not reach significant results in some of the calculations.

\section{Conclusions}

Complications in pc-RPLND represent a multifaceted problem because adverse events may result from a large number of factors. In the present study, the rate of grade III-IV complications according to the CD system was 14.4\% (no postoperative mortality), which is in line with most of the previous reports on this subject. We conclude that it is problematic to define a benchmark or an upper (acceptable) limit of complications because at least three factors may affect complication rates: first, patient-related factors including extent of surgery and comorbidities, second, methodological considerations in rating clinical events as complication, and third, surgical expertise. All in all, retroperitoneal lymph node dissection in patients with testicular cancer represents major surgery with a high potential of adverse events. Any surgeon active in this field must be prepared to manage adverse events occurring intraoperatively or during the postoperative course. Patients with testis cancer requiring such type of surgery are probably best advised to attend high-volume specialised referral centres.

\section{Abbreviations}

RPLND: Retroperitoneal lymph node dissection; p-RPLND: Primary (open) RPLND; I-RPLND: Laparoscopic RPLND; pc-RPLND: Post-chemotherapy RPLND; GCT: Germ cell tumour; BMI: Body mass index; CD: Clavien-Dindo

\section{Acknowledgements \\ Not applicable}

\section{Authors' contributions}

CGR and KPD conceived the study; SK and PA gathered and compiled the clinical data; HI performed statistical analysis; HI, CGR, TN, and KPD accomplished analysis and interpretation of data; CM and KPD were directly responsible for patient care and performed many of the operations; JS did manuscript writing and editing, data management; all authors read and approved the final manuscript. 


\section{Funding}

The present study did not receive any funding.

\section{Availability of data and materials}

The datasets used and/or analysed during the current study are available from the corresponding author on reasonable request.

\section{Ethics approval and consent to participate}

Ethical consent was obtained from institutional Ethical Committee (AEK: U03, Hamburg 12 June 2016).

Written consent was obtained from the patient to publish MRI image of lymphocele (Fig. 1 of manuscript).

\section{Consent for publication}

Written consent was obtained from the patient for publishing his MRI findings in Fig. 1.

\section{Competing interests}

The authors declare that they have no competing interests.

\section{Author details}

'Department of Urology, Bundeswehrkrankenhaus Hamburg, Lesserstraße 180, 22049 Hamburg, Germany. ${ }^{2}$ Department of Urology, Bundeswehrkrankenhaus Ulm, Oberer Eselsberg 40, 89081 Ulm, Germany. ${ }^{3}$ Department of Urology, Albertinen Krankenhaus Hamburg, Suentelstrasse 11a, 22457 Hamburg, Germany. ${ }^{4}$ Department of Urology, Bundeswehrzentralkrankenhaus Koblenz, Rübenacher Str. 170, 56072 Koblenz, Germany. ${ }^{5}$ Department of Urology, Ortenau-Klinikum, Ebertplatz 12, 77654 Offenburg, Germany. ${ }^{6}$ Martini Klinik, Universitätsklinikum Eppendorf, Martinistrasse 52, 20246 Hamburg, Germany. ${ }^{7}$ Department of Urology, Asklepios Klinik Altona, Paul Ehrlich Strasse 1, 22763 Hamburg, Germany.

Received: 31 May 2020 Accepted: 18 September 2020

\section{Published online: 24 September 2020}

\section{References}

1. Hanna NH, Einhorn LH. Testicular cancer - discoveries and updates. N Engl J Med. 2014:371:2005-16.

2. Rajpert-De Meyts E, McGlynn KA, Okamoto K, Jewett MA, Bokemeyer C. Testicular germ cell tumours. Lancet. 2016;387:1762-74.

3. Kocher T. §1006. In: Die Krankheiten der männlichen Geschlechtsorgane. Stuttgart: Ferdinand Enke Verlag; 1887. p. 491-2.

4. Donohue JP. Evolution of retroperitoneal lymphadenectomy (RPLND) in the management of non-seminomatous testicular cancer (NSGCT). Urol Oncol. 2003:21:129-32

5. Heidenreich A, Paffenholz P, Nestler T, Pfister D. Primary and postchemotherapy retroperitoneal lymphadenectomy for testicular cancer. Oncol Res Treat. 2018;41:370-8.

6. Albers P, Albrecht W, Algaba F, Bokemeyer C, Cohn-Cedermark G, Fizazi K, Horwich A, Laguna MP, Nicolai N, Oldenburg J. Guidelines on testicular cancer: 2015 Update. Eur Urol. 2015;68:1054-68.

7. Gilligan T, Lin DW, Aggarwal R, Chism D, Cost N, Derweesh $\mathbb{H}$, Emamekhoo H, Feldman DR, Geynisman DM, Hancock SL, et al. Testicular cancer, Version 2.2020, NCCN Clinical Practice Guidelines in Oncology. J Natl Compr Canc Netw. 2019;17:1529-54.

8. Williams SB, McDermott DW, Dock W, Bahnson E, Berry AM, Steele GS, Richie JP. Retroperitoneal lymph node dissection in patients with high risk testicular cancer. J Urol. 2009:181:2097-102.

9. Dieckmann KP, Anheuser P, Kulejewski M, Gehrckens R, Feyerabend B. Is there still a place for retroperitoneal lymph node dissection in clinical stage 1 nonseminomatous testicular germ-cell tumours? A retrospective clinical study. BMC Urol. 2018;18:95. https://doi.org/10.1186/s12894-12018-10412-x.

10. Daneshmand S. Refining the role of primary retroperitoneal lymph node dissection in the management of early-stage testicular cancer. Curr Opin Urol. 2020;30:234.

11. Kunit $T$, Janetschek $G$. Minimally invasive retroperitoneal lymphadenectomy: current status. Urol Clin North Am. 2015:42:321-9.

12. Cary C, Masterson TA, Bihrle R, Foster RS. Contemporary trends in postchemotherapy retroperitoneal lymph node dissection: Additional procedures and perioperative complications. Urol Oncol. 2015;33:389 e315-321.
13. Tanaka T, Kitamura H, Kunishima Y, Takahashi S, Takahashi A, Masumori N, Itoh N, Tsukamoto T. Modified and bilateral retroperitoneal lymph node dissection for testicular cancer: peri- and postoperative complications and therapeutic outcome. Jpn J Clin Oncol. 2006;36:381-6.

14. Sheinfeld J, Herr HW. Role of surgery in management of germ cell tumor. Sem Oncol. 1998:25:203-9.

15. Subramanian VS, Nguyen CT, Stephenson AJ, Klein EA. Complications of open primary and post-chemotherapy retroperitoneal lymph node dissection for testicular cancer. Urol Oncol. 2010;28:504-9.

16. Macleod LC, Rajanahally S, Nayak JG, Parent BA, Ramos JD, Schade GR, Holt SK, Dash A, Gore JL, Lin DW. Characterizing the morbidity of postchemotherapy retroperitoneal lymph node dissection for testis cancer in a national cohort of privately insured patients. Urology. 2016;91:70-6.

17. Albers $P$, Melchior D, Müller SC. Surgery in metastatic testicular cancer. Eur Urol. 2003:44:233-44.

18. Dindo D, Demartines N, Clavien PA. Classification of surgical complications: a new proposal with evaluation in a cohort of 6336 patients and results of a survey. Ann Surg. 2004;240:205-13.

19. Poletajew S, Zapała L, Piotrowicz S, Wołyniec P, Sochaj M, Buraczyński P, Lisiński J, Swiniarski P, Radziszewski P, Association. RSoPU. Interobserver variability of Clavien-Dindo scoring in urology. Int J Urol. 2014;21:1274-8.

20. Mitropoulos D, Artibani W, Biyani CS, Bjerggaard Jensen J, Rouprêt M, Truss M. Validation of the Clavien-Dindo Grading System in Urology by the European Association of Urology Guidelines Ad Hoc Panel. Eur Urol Focus. 2018;4:608-13.

21. de la Rosette JJ, Opondo D, Daels FP, Giusti G, Serrano A, Kandasami SV, Wolf JSJ, Grabe M, Gravas S, Group. CPS. Categorisation of complications and validation of the Clavien score for percutaneous nephrolithotomy. Eur Urol. 2012;62:246-55.

22. Donohue JP, Foster RS, Rowland RG, Bihrle R, Jones J, Geier G. Nervesparing retroperitoneal lymphadenectomy with preservation of ejaculation. J Urol. 1990;144:287-91.

23. Dieckmann KP, Gross AJ, Huland H. A test for the identification of relevant sympathetic nerve fibers during nerve-sparing retroperitoneal lymphadenectomy. J Urol. 1992;148:1450-2.

24. Souchon R, Krege S, Schmoll HJ, Albers P, Beyer J, Bokemeyer C, Classen J, Dieckmann KP, Hartmann M, Heidenreich A, et al. Interdisziplinärer Konsensus zur Diagnostik und Therapie von Hodentumoren. Ergebnisse einer Update-Konferenz auf Grundlage evidenzbasierter Medizin (EBM). Strahlenther Onkol. 2000;176:388-405.

25. Krege S, Beyer J, Souchon R, Albers P, Albrecht W, Algaba F, Bamberg M, Bodrogi I, Bokemeyer C, Cavallin-Ståhl E, et al. European Consensus Conference on Diagnosis and Treatment of Germ Cell Cancer: A Report of the Second Meeting of the European Germ Cell Cancer Consensus group (EGCCCG): Part I. Eur Urol. 2008:53:478-96.

26. Weissbach L, Boedefeld EA, Testicular tumor study group. Localization of solitary and multiple metastases in stage II nonseminomatous testis tumor as basis for a modified stagimng lymph node dissection in stage I. J Urol. 1987;138:77-82

27. Pottek T. Retroperitoneale Lymphadenektomie beim Hodentumor. Urologe A. 2004:43:1514-20.

28. Spiess PE, Brown GA, Liu P, Tannir NM, Tu SM, Evans JG, Czerniak B, Kamat AM, Pisters LL. Predictors of outcome in patients undergoing postchemotherapy retroperitoneal lymph node dissection for testicular cancer. Cancer. 2006;107:1483-90.

29. Fléchon A, Tavernier E, Boyle H, Meeus P, Rivoire M, Droz JP. Long-term oncological outcome after post-chemotherapy retroperitoneal lymph node dissection in men with metastatic nonseminomatous germ cell tumour. BJU Int. 2010;106:779-85.

30. Luz MA, Kotb AF, Aldousari S, Brimo F, Tanguay S, Kassouf W, Aprikian AG. Retroperitoneal Lymph Node Dissection for Residual Masses after Chemotherapy in Nonseminomatous Germ Cell Testicular Tumor. World J Surg Oncol. 2010;8:97.

31. Wells H, Hayes MC, O'Brien T, Fowler S. Contemporary retroperitoneal lymph node dissection (RPLND) for testis cancer in the UK - a national study. BJU Int. 2017:119:91-9.

32. Hendry WF, Norman AR, Dearnaley DP, Fisher C, Nicholls J, Huddart RA, Horwich A. Metastatic nonseminomatous germ cell tumors of the testis: results of elective and salvage surgery for patients with residual retroperitoneal masses. Cancer. 2002;94:1668-76.

33. Djaladat H, Nichols C, Daneshmand S. Adjuvant Surgery in Testicular Cancer Patients Undergoing Postchemotherapy Retroperitoneal Lymph Node Dissection. Ann Surg Oncol. 2012;19:2388-93. 
34. Considine S, Heaney R, Conroy R, Thornhill JA. Post-chemotherapy retroperitoneal lymph node dissection in the management of metastatic testis cancer: the 16-year experience in an Irish setting. Ir J Med Sci. 2016; 185:901-7.

35. Dusaud M, Malavaud B, Bayoud Y, Sebe P, Hoepffner JL, Salomon L, Houlgatte A, Pignot G, Rigaud J, Fléchon A, et al. Post-chemotherapy retroperitoneal teratoma in nonseminomatous germ cell tumors: Do predictive factors exist? Results from a national multicenter study. J Surg Oncol. 2016;114:992-6.

36. Paffenholz $P$, Pfister $D$, Heidenreich A. Postchemotherapy residual tumour resection in complex metastatic sites of advanced testicular germ cell tumours. Article in German. Urologe A. 2016;55:632-40.

37. Hiester A, Nini A, Fingerhut A, Große Siemer R, Winter C, Albers P, Lusch A. Preservation of ejaculatory function after postchemotherapy retroperitoneal lymph node dissection (PC-RPLND) in patients with testicular cancer: template vs. bilateral resection. Front Surg. 2019;5:80. https://doi.org/10. 3389/fsurg.2018.00080 eCollection 02018.

38. Gerdtsson A, Håkansson U, Törnblom M, Jancke G, Negaard HFS, Glimelius I, Halvorsen D, Karlsdóttir Á, Haugnes HS, Andreassen KE, et al. Surgical complications in postchemotherapy retroperitoneal lymph node dissection for nonseminoma germ cell tumour: a population-based study from the Swedish Norwegian Testicular Cancer Group. Eur Urol Oncol. 2020;3:382-9.

39. Blok JM, Meijer RP, van der Poel HG, Bex A, van Vooren J, van Urk JJ, Horenblas $\mathrm{S}$, Bosch JLHR. Additional surgical procedures and perioperative morbidity in post-chemotherapy retroperitoneal lymph node dissection for metastatic testicular cancer in two intermediate volume hospitals. World J Urol. 2020 https:/doi.org/10.1007/s00345-020-03229-5 [Epub ahead of print].

40. Gels ME, Nijboer AP, Hoekstra HJ, Sleijfer DT, Molenaar WM, Plukker JT, Droste JH, Schraffordt Koops H. Complications of the post-chemotherapy resection of retroperitoneal residual tumour mass in patients with nonseminomatous testicular germ cell tumours. Br J Urol. 1997;79:263-8.

41. Tandstad T, Kollmannsberger CK, Roth BJ, Jeldres C, Gillessen S, Fizazi K, Daneshmand S, Lowrance WT, Hanna NH, Albany C, et al. Practice makes perfect: the rest of the story in testicular cancer as a model curable neoplasm. J Clin Oncol. 2017;35:3525-8.

42. Capitanio U, Jeldres $C$, Perrotte $P$, Isbarn H, Crépel M, Cloutier V, BaillargeonGagne S, Shariat SF, Duclos A, Arjane P, et al. Population-based study of perioperative mortality after retroperitoneal lymphadenectomy for nonseminomatous testicular germ cell tumors. Urology. 2009;74:373-7.

43. Albany C, Kesler K, Cary C. Management of Residual Mass in Germ Cell Tumors After Chemotherapy. Curr Oncol Rep. 2019;21:5. https://doi.org/10. 1007/s11912-11019-10758-11916.

44. Lusch A, Albers P. Residual tumor resection (RTR). World J Urol. 2017;35: 1185-90.

45. Honecker F, Aparicio J, Berney D, Beyer J, Bokemeyer C, Cathomas R, Clarke N, Cohn-Cedermark G, Daugaard G, Dieckmann KP, et al. ESMO Consensus Conference on testicular germ cell cancer: diagnosis, treatment and followup. Ann Oncol. 2018;29:1658-86.

46. Steyerberg EW, Gerl A, Fossa SD, Sleijfer DT, de Wit R, Kirkels WJ, Schmeller N, Clemm C, Habbema JD, Keizer HJ. Validity of predictions of residual retroperitoneal mass histology in nonseminomatous testicular cancer. J Clin Oncol. 1998;16:269-74

47. Winter C, Pfister D, Busch J, Bingöl C, Ranft U, Schrader M, Dieckmann KP, Heidenreich A, Albers P. Residual tumor size and IGCCCG risk classification predict additional vascular procedures in patients with germ cell tumors and residual tumor resection: a multicenter analysis of the German Testicular Cancer Study Group. Eur Urol. 2012;61:403-9.

48. Patel HD, Ball MW, Cohen JE, Kates M, Pierorazio PM, Allaf ME. Morbidity of urologic surgical procedures: an analysis of rates, risk factors, and outcomes. Urology. 2015;85:552-9.

49. DeMaria EJ, Carmody BJ. Perioperative management of special populations: obesity. Surg Clin North Am. 2005;5:1283-9.

50. Bazurro S, Ball L, Pelosi P. Perioperative management of obese patient. Curr Opin Crit Care. 2018;24:560-7.

51. Slankamenac K, Graf R, Barkun J, Puhan MA, Clavien PA. The comprehensive complication index: a novel continuous scale to measure surgical morbidity. Ann Surg. 2013;258:1-7.

52. Yamamoto $T$, Takahashi $S$, Ichihara $K$, Hiyama $Y$, Uehara $T$, Hashimoto J, Hirobe M, Masumori N. How do we understand the disagreement in the frequency of surgical site infection between the CDC and Clavien-Dindo classifications? J Infect Chemother. 2015;21:130-3.
53. Elkoushy MA, Luz MA, Benidir T, Aldousari S, Aprikian AG, Andonianm S. Clavien classification in urology: Is there concordance among post-graduate trainees and attending urologists? Can Urol Assoc J. 2013;7:179-84.

54. Rassweiler JJ, Rassweiler MC, Michel MS. Classification of complications:: Is the Clavien-Dindo classification the Gold standard? Eur Urol. 2012;62:256-60.

55. Katayama H, Kurokawa Y, Nakamura K, Ito H, Kanemitsu Y, Masuda N, Tsubosa Y, Satoh T, Yokomizo A, Fukuda H, Sasako M. Extended ClavienDindo classification of surgical complications: Japan Clinical Oncology Group postoperative complications criteria. Surg Today. 2016;46:668-85.

56. Vahlensieck W, Beltz L, Weissbach L. Retro- and intraperitoneal lymph fistula following semicastration and transperitoneal lymphadenectomy in testicular tumors (author's transl). Urol Int. 1973;28:453-8.

57. Vahlensieck EW, Jaeger N, Widman T. Ursachen, Prävention und Behandlung von Komplikationen der lymphadenektomie beim Hodentumorpatienten. Urologe A. 1985;24:137-41.

\section{Publisher's Note}

Springer Nature remains neutral with regard to jurisdictional claims in published maps and institutional affiliations.

Ready to submit your research? Choose BMC and benefit from

- fast, convenient online submission

- thorough peer review by experienced researchers in your field

- rapid publication on acceptance

- support for research data, including large and complex data types

- gold Open Access which fosters wider collaboration and increased citations

- maximum visibility for your research: over $100 \mathrm{M}$ website views per year

At BMC, research is always in progress.

Learn more biomedcentral.com/submissions 